\title{
Demografik Özellikler ve Psikolojik Sahiplenme: Havacılık Sektöründe Bir Araştırma
}

\author{
Demographic Features and Psychological Ownership: A Research In The Aviation \\ Sector
}

\author{
Öğr. Gör. Dr. Leyla ŞENOL (iD), Dr. Burcu ÜZÜM(D2
}

\begin{abstract}
$\ddot{\mathbf{O} z}$
$\mathrm{Bu}$ araştırmadaki amaç; işgörenlerin sahip oldukları demografik değişkenlerin psikolojik sahiplenme üzerindeki farklılık yaratıp yaratmadığının belirlemektir. Araştırma için gerekli olan veriler hava yolu çalışanlarından sağlanmıştır. Hava yolu işletmelerinde çalışanların psikolojik sahiplenme düzeylerinin tespit edilmesi için nicel yöntem tercih edilmiştir. Belirlenen yöntem dahilinde anket ile veri toplanmıştır. Elde edilen sonuçlar IBM SPSS 21 yazılım programı ile analiz edilmiştir. Araştırmada Uçar (2018) tarafından geliştirilen dört boyutlu psikolojik sahiplenme ölçeği kullanılmıştır. Anket formunda ayrıca cinsiyet, gelir, medeni durum, eğitim durumu, yaş ve pozisyon gibi demografik sorularda bulunmaktadır. Analizlerde anlamlılık derecesi 0,05 olarak kabul edilmiştir. Verilere AFA, DFA, güvenirlik, korelasyon, ANOVA analizi ile t-testi uygulanmıştır. DFA için LISREL 9.1 paket programı kullanılmıştır. Araştırma sonucunda; demografik değişkenlerden cinsiyet, medeni durum, yaş ile psikolojik sahiplenme ve alt boyutları arasında istatistiki bir ilişki bulunamamıştır. Ancak gelir ve pozisyon ile psikolojik sahiplenme arasında anlamlı bir ilişki tespit edilmiştir. Gelir arttıkça psikolojik sahiplenmede artış olduğu belirtilebilir. Ayrıca hiyerarşik pozisyon yükseldikçe psikolojik sahiplenme düzeyi de artmaktadır.
\end{abstract}

Anahtar Kelimeler: Psikolojik sahiplenme, demografik değişkenler, tutum ve davranışlar, havacılık sektörü

Makale Türü: Araştırma

\begin{abstract}
The aim of this research; It is to determine whether demographic variables that employees have make a difference on psychological ownership. The data required for the research was provided from the airline staff. Quantitative method was used to determine the psychological ownership level of the employees in the airline companies. Data were collected by questionnaire within the determined method. The results were analyzed with IBM SPSS 21 software. Four-dimensional psychological ownership scale developed by Uçar (2018) was used in the study. The questionnaire also includes demographic questions such as gender, income, marital status, educational background, age and position. The degree of significance was accepted as 0.05 in the analysis. AFA, CFA, reliability, correlation, ANOVA analysis and t-test were applied to the data. The LISREL 9.1 package program was used for DFA. As a result of the research, there was no statistical relationship between demographic variables, gender, marital status, age and psychological ownership and sub-dimensions. However, a significant relationship was found between income and position and psychological ownership. It can be stated that as income increases, there is an increase in psychological ownership. In addition, as the hierarchical position increases, the level of psychological ownership increases.
\end{abstract}

Keywords: Psychological ownership, demographic variables, attitudes and behaviors, aviation sector Paper Type: Research

\footnotetext{
${ }^{1}$ Kocaeli Üniversitesi, Ali Rıza Veziroğlu Meslek Yüksekokulu, senolleyla4@gmail.com.

${ }^{2}$ Kocaeli Üniversitesi, Kocaeli Meslek Yüksekokulu, burcugokay@gmail.com.
}

Atıf için (to cite): Şenol, L., Üzüm, B. (2020). Demografik özellikler ve psikolojik sahiplenme: havacılık sektöründe bir araştırma. Afyon Kocatepe Üniversitesi Sosyal Bilimler Dergisi, 22(3), 760-770. 


\section{Giriş}

Örgütlerin hedeflerine ulaşma yolunda en önemli kaynaklarından biri insan kaynağıdır. Bu önemli kaynağın verimli şekilde kullanılması örgütlerin amaçlarından biri olarak yönetimde yer etmiştir. Yönetim ve çalışma endüstrisi açısından insan hem fiziksel hem de ruhsal yönden bir bütün olarak ele alınmaktadır. Çalışanlar; örgütü başarıya ulaştırırken ve işletme performansına da doğrudan etkilemektedirler.

Başarı ve üstün performans sağlayan çalışanların davranış ve tutumları pozitif örgütsel davranış kapsamında incelenmektedir. Örgütsel davranış yazınında incelenen kavramlardan biri de psikolojik sahiplenmedir. İnsanın doğasında yer edinmiş bir tutum olarak sahip olma isteği; soyut kavramlara veya somut nesnelere yönelik geliştirilebilir (Asatryan \& Oh, 2008, s.363). Sahip olma isteği ile geliştirilen bu hislerden biri de psikolojik sahiplenmedir. Psikolojik sahiplenmenin önemi ise psikolojik ve tutumsal etkilerinin olmasından gelmektedir (Isaacs 1933, akt., Uçar, 2017, s. 168).

Yasal mülkiyet hakkına sahip olmamasına rağmen sanki kendine aitmiş gibi örgütü sahiplenen çalışanlar, tutumsal olarak işletmenin verimliliğine ve performansına olumlu katkıda bulunmaktadır. Bu durum işletmelerin rekabet gücünü ve hizmet kalitesini artırmada etkili olmaktadır. Psikolojik sahiplenmeyi etkileyen unsurların belirlenmesi örgüt başarısını artırmaya yardımcı olacaktır. Psikolojik sahiplenme düzeyindeki artış iş memnuniyetinin, örgütsel bağlılığın, motivasyonun, çalışan performansının yükselmesine katkı sağlamaktadır (Temizkan, 2019, s. 642). Psikolojik sahiplenme kavramının hastane, banka çalışanları, öğretmenler ve sektör çalışanları üzerinde çalışıldığı görülmüştür.

Hizmet sektörü içerisinde yer alan havacılık sektörü çalışanlarının kurumlarına karşı psikolojik sahiplenme düzeylerinin demografik değişkenlerle olan ilişkisinin araştırıldı ̆̆ bu çalışma sonuçlarının örgütsel davranış literatürüne ve gelişmekte olan Türk havacılık sektörüne katkı sağlayacağı düşünülmektedir.

\section{Psikolojik Sahiplenme}

Psikolojik sahiplenme sosyoloji, felsefe, insan gelişimi ve psikoloji bilimlerinin inceleme konusu olmuştur (Pierce vd., 2001, s. 296). Psikolojik sahiplenmenin sadece biçimsel sahiplik değil büyüyerek gelişen bir olgu olduğu belirtilmiş̧tir (Pierce vd., 1991, s.310). Psikolojik sahiplenme resmi sahiplikten ayrı bir kavram olarak ele alınmış, sonrasında da psikolojik sahiplenme bir teori olarak ortaya konmuştur (Pierce vd., 2001, s. 310). Psikolojik sahiplenme; yasal veya yasal olmayan sahiplenmenin olmadığ 1 ortamda var olan bir sahiplenme arzusudur (Mayhew vd., 2007, s. 477; Van Dyne ve Pierce, 2004, s. 459).

Örgütsel açıdan psikolojik sahiplenme gelişimi, psikoloji ve sosyoloji araştırmalarına dayanmaktadır. Bu bağlamda çalışan ile ilgili psikolojik sahiplenmenin oluşumunu sağlayan güdüler üzerinde yoğunlaşılmıştır (Pierce vd., 2004, s. 459; Pierce ve Rodgers, 2004, s. 613; Van Dyne ve Pierce, 2004, s. 459; Mayhew vd., 2007, s. 500). Kolektif psikolojik sahiplenmenin sosyolojik temelde de ele alınabileceği ortaya konulmuştur (Pierce ve Jussila, 2010, s. 834). Ancak psikolojik sahiplenme, örgütsel açıdan psikolojik temelli çalışmalar etrafında toplanmıştır (Uçar, 2017, s. 167).

Bu bağlamda psikolojik sahiplenme; çalışanın birtakım nesneleri kendisine aitmiş gibi hissetmesi, çalışanın örgütüne duyduğu psikolojik sahiplenme ise, çalışanın örgütün kendisine aitmiş gibi hissetmesi şeklinde açıklanmaktadır (Pierce vd., 2003, akt., Yeşil vd., 2015, s. 65).

Araştırmalara göre sahiplenilen soyut veya somut nesneler, benliğin bir devamı şeklinde görülmekte ve genellikle de sahip olunan varlıkların bir toplamı olarak benliği açıklamaktadır (Litwinski, 1947, s. 240; Belk, 1988, s. 139; Yeşil vd., 2015, s. 61). Psikolojik sahiplenme; tutumlarla, benlik kavramıyla ve sorumluluk duygusuyla ilişki içindedir. Bireyler soyut ve somut nesnelere karşı sahiplik hissettiğinde onlara karşı daha olumlu tutum geliştirmekte hatta 
benliklerinin devamı olarak görüp sahiplik hissettikleri nesnelere karşı sorumluluk duygusu geliştirmektedirler. Bu sorumluluk duygusu da kendini iş doyumu örgütsel bağlllık gibi örgütsel davranışta kendini yansıtmaktadır (Van Dyne ve Pierce, 2004, s. 459).

Bireylerin çeşitli hedeflere yönelik sahiplenme hissettiği gözlemlenmektedir, belirli şartlar sağlandığında örgüt çalışanlarının kuruma ve çeşitli örgütsel unsurlara karşı sahiplenme hisleri geliştirebilmektedir. Örgütlerle psikolojik ilişkiler, taahhüt, tanımlama ve içselleştirme psikolojik mülkiyet ile bir arada bulunabilir (Pierce vd., 2001, s. 298). Psikolojik sahiplenme örgüte, çalışanlara, fikre, öneriye, işe veya ekipmana karşı duyulan sahiplenme gibi çeşitli şekillerde ortaya çıkabilmektedir (Van Dyne ve Pierce, 2004, s. 439).

Yapılan araştırmalar resmi sahiplenmenin kamusal anlamda yasal dayanaklara sahip olduğunu, psikolojik olarak sahiplenmenin ise çalışanların kişisel duygularına dayandığını göstermektedir. Sahiplik duygusuna ait üç önemli nokta tanımlanmaktadır (Pierce vd., 2001, s. 298; Pierce vd., 2003, akt., Yeşil vd., 2015, s. 65). Birinci nokta, sahiplik duygusunun insana ait bir olgu olduğu; ikincisinin insanların çevresindeki soyut ve somut tüm nesnelere yönelik geliştirilen hisler olduğudur. Üçüncü nokta ise; sahiplik hissinin önemli tutumsal, duygusal ve psikolojik çıktılarının olmasıdır (Pierce vd., 2003, akt., Yeşil vd., 2015, s. 65; Memmedova ve Ekber, 2017, s. 100). Mülkiyet sahipliği kavramı öz kimlik, etkililik/etkileme, bölgecilik ve sorumluluk olarak dört boyutta ele alınmaktadır (Uçar, 2017, s. 177).

Çalışanın örgütüne karşı sahiplik hissetmesi, psikolojik anlamda örgütüne bağlanması örgüt kimliği kapsamında yer almaktadır (McIntyre vd., 2009, s. 383). Psikolojik sahiplenme ve örgüte bağlılık arasında güçlü bir ilişki olsa da bu iki olgu ayrı kavram olarak ele alınmaktadır (Mayhew vd., 2007, s. 500). Psikolojik sahiplenmenin yarattığı örgütsel bağlılık; çalışanların örgütün hedefleriyle bütünleştiği bir tutumu yansitmaktadır (Pierce vd., 2004, akt., Yeşil vd., 2015, s. 66). Psikolojik sahiplenme hissi taşıyan kişiler örgüte bağlılık gibi pozitif davranışlar göstermektedir.

Psikolojik sahiplenme farklı yazarlar tarafindan farklı boyutlarla ele alınmıştır. Psikolojik sahiplenme geliştirici ve önleyici olmak üzere iki şekilde görülebilmektedir (Avey vd., 2009). Ayrica Dirik ve Eryılmaz (2016, s. 1435), promosyon odaklı psikolojik sahiplenmeden de söz etmişlerdir. Promosyon odaklı psikolojik sahiplenmede mülkiyet önceliği ilk sırada yer almazken, mülkiyet sahipliği özendirici bir konumda yer almaktadır ve öz yeterlilik, hesap verebilirlik, aidiyet duygusuyla öz kimlik olarak dört boyuttan oluşmaktadır.

\subsection{Psikolojik Sahiplenme ve İlişkili Olduğu Kavramlar}

Psikolojik açıdan olumlu duygular beslenmeye (Van Dyne ve Pierce, 2004, s. 439) yatkınlık, genellikle benlik ile ilgili bir durumu ifade etmektedir. Başka bir ifadeyle kişiler sahip oldukları bağlamında diğer kişilere kendilerini anlatma, benliklerini ifade etme ve zaman içinde öz devamlılıklarını sürdürmeyi hedeflemektedir (Pierce vd., 2001, s. 300). Bu açıdan sahiplik hissi hedef, kimliğin bir devamı olarak anlaşılmakta ve kişinin öz benliği kapsamında köklü bir yap1 oluşturmaktadır (Uçar, 2018, s. 643). Sahiplenme, bireyler açısından psikolojik temelli "benimki” kimliğine dönüşmekte ve kişi kendi benliğini onun üzerinden yapılandırmaktadır. Kişi onunla var oldukça psikolojik sahipliğin hedefi bireyin benliği üzerinde, kimliğinin bir parçasına ve kimliğini ifade eden bir sembol haline gelmektedir (Pierce vd., 2001, s. 299; Avey vd., 2009, s. 174).

Sahiplenmenin temelinde bulunan güdü, kontrolü elinde tutmaktadır. Bireylerin herhangi bir nesne üzerindeki kontrolü veya inisiyatiflerinin olması, etkililik duygusunu meydana getirmektedir. Sahiplik ile birlikte gelen haklar, kişilerin çevresini anlamalarına ve onu değiştirmelerine olanak tanıyarak etkili olma duygusunu tatmin etmelerini sağlamaktadır. Kişilerin çevrelerini değiştirme arzuları, onların sahiplenme arzusunun gelişmesine neden olmaktadır (Pierce vd., 2001, s. 300). 
Bölgecilik; kişinin kendi alanının sınırlarının çizilmesi ve onun korunmaya çalışılması (Avey vd., 2009, s. 174) olarak açıklanabilir. Psikolojik sahiplenme yazın alanında koruyucu odak bileşenini açıklayan kavram olarak görülmektedir. Bölgecilik, kişinin fiziksel veya sosyal sahipliğin hedefine dair sahiplik duygusunun tutumsal yönü olarak açıklanmaktadır (Brown vd., 2005, s. 577).

Psikolojik sahiplenme alanında yer alan diğer bir kavram da sorumluluktur. Soyut bir kavram olarak açıklanan sorumluluk dört özellik ile açıklanmaktadır. Bu özelliklerden sorumluluğun bir süreç olarak ele alındığ 1 , sorumluluğun tercih edildiği, sorumluluğun içsel bir süreç olarak ve sorumluluğun bir anlamda öz açıklama olduğu anlaşılmaktadır (Nelson-Jones, 1984, s. 3).

Sorumluluk, bireyin inançlarını, hislerini ve davranışlarını diğer bireylere onaylatmak üzere ortaya koyacağı gizli veya açık beklentileri şeklinde açıklanmaktadır. Sorumluluk psikolojik sahiplenme kapsamında bir bileşen olarak yer almaktadır ve iki yönlü olarak değerlendirilmektedir (Avey vd., 2009, s. 173). Bunlar, bireyin diğerlerini sorumlu tutmaya yönelik beklentisi ve bireyin kendini sorumlu tutmasıdır (Lerner ve Tetlock 1999, s. 255). Bir başka ifadeyle; psikolojik sahipliğin hesap verebilme yönüyle kişiler hem diğerlerini sorumlu tutabilme hem de içsel açıdan öz-sorumluluk duygusu oluşmaktadır.

Örgütsel davranış yazınında; psikolojik sahiplenme ile örgütsel destek ve duygusal destek arasında olumlu yönde anlamlı bir ilişki bulunduğu tespit edilmiştir. Özellikle, psikolojik sahiplenme ve duygusal destek arasında daha yüksek derecede bir ilişki bulunduğu sonucuna varılmıştır. Örgütsel destek arttıkça örgüte karşı psikolojik sahiplenmenin arttığını belirtmek mümkündür (Ökten, 2015, s. 140). Örgüt için psikolojik sahiplik ile çalışan tutumları (örgütsel bağl1lık, iş tatmini, organizasyon temelli öz saygı) ve iş davranışı (performans ve örgütsel vatandaşlık) arasında olumlu yönde anlamlı bir ilişki olduğunu göstermektedir (Van Dyne ve Pierce, 2004, s. 459).

Psikolojik sahiplenmeyle örgütsel destek, örgütsel adalet, (Ökten, 2015), sanal kaytarma, yenilikçi iş davranışları (Derin, 2018), algılanan kontrol (Kalyoncuoğlu, 2018), kontrol alg1sı (Uçar, 2016), işkoliklik (Dirik ve Eryılmaz, 2016), etik olmayan örgütsel davranışlar (Karadal ve Akyazı, 2015), babacan liderlik (Bekmezci ve Yıldız, 2019) gibi kavramların birlikte araştırıldığı görülmüştür.

\section{Yöntem}

Nicel yöntemin tercih edildiği araştırmada veriler anket yöntemi ile elde edilmiştir. Anketler 2019 yılında ocak-şubat aylarında dağıtılmış ve toplanmıştır. Anket; psikolojik sahiplenme ölçeği ve demografik sorular olarak iki bölümden oluşmaktadır. Araştırmanın ilk bölümünde kullanılan psikolojik sahiplenme ölçeğinin geliştirme çalışması Uçar (2018) tarafından yapılmıştır. Ölçek 15 maddeden; etkililik, koruyucu odak, kimlikleştirme ve sorumluluk olarak dört alt boyuttan oluşmaktadır. Anket formu 5'li likert tipinde hazırlanmıştır. Ölçeğin güvenirliği 0,922 olarak hesaplanmıştır. Araştırmanın ikinci bölümünde katılımcılara ilişkin cinsiyet, gelir, medeni durum, eğitim durumu, yaş, pozisyon olarak demografik değişkenlerin tespit edilmesine yönelik sorular sorulmuştur.

\subsection{Katılımcilar}

Araştırma evreni, Sabiha Gökçen Havaalanı ve Cengiz Topel Havaalanında faaliyet gösteren iki farklı özel havayolu şirketi çalışanlarından oluşmaktadır. Evren 270 kişidir. Kolayda örneklem metodunun tercih edildiği araştırma 178 çalışana gönüllü katılım esasına göre uygulanmıştır. Örneklem sayısına göre anketlerin geri dönüş oranı \%65,92'dir.

\section{Bulgular}


Verilerin IBM SPSS 21 ve LISREL 9.1 programı ile analiz edildiği araştırmada anlamlılık değeri 0,05 olarak kabul edilmiştir. Normal dağılım gösteren verilere açımlayıcı, doğrulayıcı faktör analizi, korelasyon analizi, t-testi, tek yönlü varyans analizi uygulanmıştır.

Araştırma; demografik değişkenlerin psikolojik sahiplenme ve alt boyutları üzerinde bir farklılık yaratıp yaratmadığının incelenmesini amaçlamaktadır. $\mathrm{Bu}$ amaç doğrultusunda hazırlanan hipotezler şöyledir;

$\mathrm{H}_{1:}$ Yaş psikolojik sahiplenme üzerinde bir farklılık yaratmaktadır,

$\mathrm{H}_{2:}$ Eğitim psikolojik sahiplenme üzerinde bir farkl11ık yaratmaktadır,

$\mathrm{H}_{3:}$ Pozisyon psikolojik sahiplenme üzerinde bir farklılık yaratmaktadır,

$\mathrm{H}_{4}$ : Medeni durum psikolojik sahiplenme üzerinde bir farkl1lık yaratmaktadır,

$\mathrm{H}_{5:}$ Cinsiyet psikolojik sahiplenme üzerinde bir farklılık yaratmaktadır,

$\mathrm{H}_{6:}$ Gelir psikolojik sahiplenme üzerinde bir farklılık yaratmaktadır,

Araştırma sonucunda elde edilen veriler ve hipotezleri test etmek amaciyla verilere uygulanan analizler ile sonuçları aşağıdaki gibi gösterilmiştir.

Tablo 1. Keiser-Meyer-Olkin ve Barlett değeri

\begin{tabular}{|c|c|c|}
\hline KMO & & 0,827 \\
\hline Barlett Testi & $\mathrm{Sd}$ & 105 \\
\hline Sig & & 0,000 \\
\hline
\end{tabular}

Keiser-Meyer-Olkin değeri 0,827 olarak hesaplanmış, Barlett testinin serbestlik derecesi 105, anlamlılık değeri ise 0,00 bulunmuştur. Birinci boyutun özdeğeri 5,205, ikinci boyutun özdeğeri 2,614, üçüncü boyutun özdeğeri 1,397 'dir. Ölçeğin açıkladığ varyans oranı 61,446 'dir.

Tablo 2. Tekrarlanan faktör analizi

\begin{tabular}{lrrr}
\hline Ölçek Maddeleri & 1. Faktör & 2. Faktör & 3. Faktör \\
\hline PSAH1 &, 752 & & \\
PSAH2 &, 795 & & \\
PSAH3 &, 851 & & \\
PSAH4 &, 460 & & \\
PSAH5 &, 719 & & \\
PSAH6 &, 752 & & \\
PSAH7 &, 682 &, 620 & \\
PSAH8 & &, 790 & \\
PSAH9 & &, 800 & \\
PSAH10 & &, 820 & \\
PSAH11 & & &, 744 \\
PSAH12 & & &, 775 \\
PSAH13 & & &, 794 \\
PSAH14 & & 2,614 & 1,397 \\
PSAH15 & & & \\
\hline Özdeğer & & & \\
(Eigenvalues) & 10,279 & & \\
Aç1klanan & 23,498 & & \\
varyans oran1 & & & \\
Toplam & 61,446 & &
\end{tabular}


Faktör yük değeri $0.30^{\prime}$ a kadar yeterli büyüklüğe sahip olduğunu belirtmek mümkündür (Büyüköztürk, 2002, s. 481). AFA uygulanırken herhangi bir faktör sayıs1 belirtilmemiş ve varimax döndürme metodu tercih edilmiştir. Kararlı bir yapıda faktörden söz edebilmek için en az 3 maddeden oluşması ve faktör yükünün yüksek olması beklenir (Karaman vd., 2017: 1180). Madde 7 kimlikleştirme boyutuna, madde 8 koruyucu odak boyutuna dağıldığından analiz üç faktör üzerinden değerlendirilmiştir. Hem AFA hem DFA sonucunda, her değişken en az üç maddeyle temsil edilmelidir.

Ölçüm model uyumluluğunu değerlendirmede en çok kullanılan değerler; $\mathrm{X}^{2}$, RMSEA, GFI değerleridir. Uyum değerlerinden, $\mathrm{X}^{2} /$ sd derecesi oranının 5 'ten küçük olması beklenirken RMSEA değerinin 0,05-0,08 arasında olması ölçme modelinin iyi bir uyuma sahip olduğunun bir göstergesidir (Şimşek, 2007).

Tablo 3. DFA uyum değerleri

\begin{tabular}{llll}
\hline Uyum İndeksleri & İyi Uyum & Kabul Edilebilir Uyum & Uyum Değerleri \\
\hline $\mathrm{X}^{2} / \mathrm{sd}$ & $\leq 3$ & $\leq 4-5$ & $\leq 4,28$ \\
RMSEA & $\leq 0,05$ & $\leq 0,06-0,08$ & $\leq 0,07$ \\
\hline
\end{tabular}

DFA sonucunda elde edilen uyum istatistik değerleri ki-kare 449,77; serbestlik derecesi 105; p değeri 0,000; RMSEA değeri 0,07'dir. Toplam 13 maddeden oluşan yapı, uyum iyiliği değerleri ile desteklenmekte kabul edilebilir değerler aralığında olduğu görülmektedir.

Tablo 4. Ölçek ait güvenirlik katsayısı

\begin{tabular}{cc}
\hline Faktör & Cronbach Alfa \\
\hline Psikolojik sahiplenme & 0,812 \\
Kimlikleştirme & 0,871 \\
Koruyucu odak & 0,809 \\
İçsel sorumluluk & 0,760 \\
\hline
\end{tabular}

Ölçeğin güvenirlik katsayısı ve alt boyutlara ait güvenirlik katsayıları; ölçeğin oldukça güvenilir olduğunu göstermektedir.

Tablo 5. Ölçeklere ilişkin korelasyon değerleri

\begin{tabular}{lllll}
\hline Değişkenler & Kimlikleştirme & $\begin{array}{c}\text { Koruyucu } \\
\text { odak }\end{array}$ & $\begin{array}{l}\text { İçsel } \\
\text { sorumluluk }\end{array}$ & $\begin{array}{l}\text { Psikolojik } \\
\text { Sahiplenme }\end{array}$ \\
\hline $\begin{array}{l}\text { Psikolojik } \\
\text { Sahiplenme }\end{array}$ & $0,869 * *$ & $0,695^{* *}$ & $0,549 * *$ & 1 \\
\hline$* * p<0,01$ & & & &
\end{tabular}

Psikolojik sahiplenme ile kimlikleştirme alt boyutu arasında $(r=, 869 ; p=0,000<0,01)$ doğru yönlü ve yüksek düzeyde, koruyucu odak alt boyutu arasında $(r=, 695 ; p=0,000<0,01)$ doğru yönlü ve yüksek düzeyde, içsel sorumluluk alt boyutu ile $(r=0,549 ; p=0,000<0,01)$ doğru yönlü ve orta düzeyde bir ilişki olduğu tespit edilmiştir.

Demografik değişkenlerle psikolojik sahiplenmenin alt boyutları arasında anlamlı bir ilişki bulunamamıştır. $\mathrm{Bu}$ nedenle sadece psikolojik sahiplenmeye ait bulgular aşağıdaki tablolarda verilmiştir.

Tablo 6. Cinsiyet ile psikolojik sahiplenme ilişkisi

\begin{tabular}{llcclll}
\hline Boyutlar & Cinsiyet & $\mathrm{N}$ & ss. & t & F & p \\
\hline Psikolojik & Erkek & 118 & 9,23 & 1,267 & 3,824 & 0,207 \\
sahiplenme & Kadın & 60 & 7,10 & & & \\
\hline
\end{tabular}


Cinsiyet ile psikolojik sahiplenme ilişkisinin incelendiği t-testi sonucuna göre varyansların eşit olduğu $(0,052)$ görülmüştür. Bu sonuca göre $(p>0,05)$, cinsiyet ile psikolojik sahiplenme arasında anlamlı bir ilişki belirlenememiştir.

Tablo 7. Gelir ile psikolojik sahiplenme ilişkisi

\begin{tabular}{lllrll}
\hline Boyut & Gelir & N & ss. & F & p \\
\hline & 1499 TL'den az & 9 & 8,63 & & \\
Psikolojik & 1500-2999 TL & 69 & 9,56 & & \\
sahiplenme & 3000-4499TL & 76 & 6,90 & \multirow{2}{*}{1,869} & \multirow{2}{*}{0,00} \\
& 4500 TL ve üzeri & 24 & 9,91 & & \\
\hline
\end{tabular}

Gelir ile psikolojik sahiplenme arasındaki ilişki tek yönlü varyans analiziyle incelenmiştir Analiz sonucunda ( $p<0,05)$, gelir ile psikolojik sahiplenme arasında anlamlı bir ilişki bulunmaktadır. Anlamlılı̆ğn hangi gruplar arasında olduğunu tespit etmek Scheffe testi yapılmıştır.

Tablo 8. Gelire ait farklılıkların analizi

\begin{tabular}{lcccc}
\hline Boyut & \multicolumn{2}{c}{ Gruplararası eşleşme } & Ortalama fark1 & $\mathrm{p}$ \\
\hline $\begin{array}{l}\text { Psikolojik } \\
\text { sahiplenme }\end{array}$ & $1500-2999 \mathrm{TL}$ & $3000-4499 \mathrm{TL}$ & $-2,95233^{*}$ & 0,039 \\
\hline
\end{tabular}

Analize göre 1500-2999 TL gelir düzeyine sahip çalışanlar 3000-4499 TL gelir düzeyine sahip çalışanlardan daha düşük psikolojik sahiplenme düzeyine sahiptirler.

Tablo 9. Medeni durum ile psikolojik sahiplenme ilişkisi

\begin{tabular}{lllllll}
\hline Boyutlar & Cinsiyet & N & ss. & t & F & p \\
\hline Psikolojik & Evli & 86 & 9,14 & 1,858 & 0,687 & 0,115 \\
sahiplenme & Bekar & 92 & 7,96 & & & \\
\hline
\end{tabular}

Medeni durum ile psikolojik sahiplenme ilişkisinin incelendiği t-testi sonucuna göre varyansların eşit olduğu $(0,408)$ görülmüştür. $\mathrm{Bu}$ sonuca göre $(\mathrm{p}>0,05)$, medeni durum ile psikolojik sahiplenme arasında anlamlı bir ilişki tespit edilmemiştir.

Tablo 10. Yaş ile psikolojik sahiplenme ilişkisi

\begin{tabular}{llrrrl}
\hline Boyut & Yaş & $\mathrm{N}$ & \multicolumn{1}{c}{ ss. } & $\mathrm{F}$ & $\mathrm{p}$ \\
\hline & $20-26$ & 51 & 9,54 & & \\
Psikolojik & $27-33$ & 50 & 8,02 & & \\
sahiplenme & $34-40$ & 61 & 8,26 & & \\
& $41-47$ & 13 & 5,31 & 2,149 & 0,077 \\
& $48-54$ & 3 & 12,22 & & \\
\hline
\end{tabular}

Yaş ile psikolojik sahiplenme arasındaki ilişki tek yönlü varyans analiziyle incelenmiştir. Analiz sonucunda ( $>$ > 0,05), yaş ile psikolojik sahiplenme arasında istatistiksel anlamlılık bulunmamaktadır.

Tablo 11. Eğitim ile psikolojik sahiplenme ilişkisi

\begin{tabular}{lllrll}
\hline Boyut & Eğitim & N & ss. & F & p \\
\hline \multirow{3}{*}{ Psikolojik } & Lise & 40 & 10,16 & & \\
sahiplenme & Önlisans & 38 & 7,67 & & \\
& Lisans & 88 & 8,14 & 0,803 & 0,49 \\
& Lisans üstü & 12 & 9,04 & & \\
\hline
\end{tabular}


Eğitim ile psikolojik sahiplenme ilişki tek yönlü varyans analiziyle incelenmiştir. Analiz sonucunda $(p>0,05)$, eğitim ile psikolojik sahiplenme arasında istatistiksel anlamlılık bulunmamaktadır.

Tablo 12. Pozisyon ile psikolojik sahiplenme ilişkisi

\begin{tabular}{llrrrl}
\hline Boyut & Pozisyon & N & \multicolumn{1}{c}{ ss. } & F & p \\
\hline & Memur & 58 & 7,904 & & \\
Psikolojik & Hizmetli & 12 & 10,762 & & \\
sahiplenme & İşçi & 21 & 10,723 & & \\
& Operasyon Elemanı & 69 & 6,710 & 5,484 & 0,000 \\
& Yönetici & 4 & 11,747 & & \\
& Şef & 14 & 7,111 & & \\
\hline
\end{tabular}

Pozisyon ile psikolojik sahiplenme arasındaki ilişkinin incelendiği tek yönlü varyans analizinin sonucuna göre $(\mathrm{p}<0,05)$, pozisyon ile psikolojik sahiplenme arasında anlamlı bir ilişki görülmektedir.

Tablo 13. Pozisyona ait farklılıkların analizi

\begin{tabular}{lcccc}
\hline Boyut & & Gruplararas1 eşleşme & Ortalama fark1 & $\mathrm{p}$ \\
\hline Psikolojik & Şef & Memur & $10,655^{*}$ & 0,002 \\
sahiplenme & Şef & İşçi & $9,4047^{*}$ & 0,050 \\
\hline
\end{tabular}

Anlamlılı̆̆ın hangi gruplar arasında olduğunu tespit etmek Scheffe testi yapılmıştır. Bu sonuçta şef ile memur arasındaki farklılık; şef ile işçi arasındaki farklılık şef pozisyonunun lehinedir. Kısaca şef pozisyonu memur ve işçiye göre daha yüksek psikolojik sahiplenme göstermektedir.

\section{Tartışma}

$\mathrm{Bu}$ araştırmada; hava yolu işletmelerinde çalışanların demografik özelliklerinin psikolojik sahiplenme düzeyine etkisi incelenmiştir. Araştırma hipotezlerinden $\mathrm{H}_{3}$ ve $\mathrm{H}_{6}$ kabul edilirken, $\mathrm{H}_{1}, \mathrm{H}_{2}, \mathrm{H}_{4}, \mathrm{H}_{5}$ reddedilmiştir. $\mathrm{Bu}$ bulguların yanı sıra demografik değişkenlerle psikolojik sahiplenmenin alt boyutlarına ilişkin yapılan analizlerde istatistiki bir anlamlılık tespit edilememiştir. Cinsiyet ile psikolojik sahiplenme arasında anlamlı bir ilişki belirlenememiştir. Elde edilen bulgular Demirkaya ve Şimşek-Kandemir (2014)' in sonuçlarıyla örtüşmektedir. Gelir ile psikolojik sahiplenme arasında anlamlı bir ilişki bulunmaktadır. Analiz sonuçlarına göre 3000-4499 TL gelir düzeyine sahip çalışanların 1500-2999 TL gelir düzeyine sahip çalışanlardan daha yüksek psikolojik sahiplenme gösterdikleri belirlenmiştir. Gelir düzeyinin artması sahiplik duygusu üzerinde de bir artış sağlamaktadır.

Demografik değişkenlerden medeni durum ile psikolojik sahiplenme arasında anlamlı bir ilişki tespit edilmemiştir. Yaş ile psikolojik sahiplenme arasında da anlamlı bir ilişki bulunmamaktadır. Eğitim ile psikolojik sahiplenme arasında istatistiki bir anlamlılık bulunmamaktadır. Fakat, Demirkaya ve Şimşek Kandemir (2014) çalışmalarında psikolojik sahiplenme ile eğitim düzeyleri arasında anlamlı bir ilişki bulmuşlardır. Yine aynı çalışmada çalışanların psikolojik sahiplenme ile çalışma süreleri arasında anlamlı bir ilişki bulunmuştur. Derin (2018)'e göre psikolojik sahiplenme yenilikçi iş davranışlarına yol açmaktadır. Memmedova ve Ekber (2017)'in yaptığ çalışma sonucuna göre de sahiplenme ile cinsiyet, yaş, kıdem, eğitim ve medeni durum arasında bir farklılık olmadığı belirlenmiştir.

Analiz sonucunda pozisyon ile psikolojik sahiplenme arasında anlamlı bir ilişki tespit edilmiştir. Şef pozisyonda çalışanların, memur ve işçiye göre daha yüksek psikolojik sahiplenme gösterdiği sonucuna ulaşılmıştır. 
Psikolojik sahiplenme ile kimlikleştirme alt boyutu arasında doğru yönlü ve yüksek düzeyde, koruyucu odak alt boyutu arasında doğru yönlü ve yüksek düzeyde, içsel sorumluluk alt boyutu ile doğru yönlü ve orta düzeyde bir ilişki olduğu tespit edilmiştir

\section{Sonuç ve Öneriler}

Pozitif örgütsel çıktıları olan psikolojik sahipliğin gelir ve pozisyonla ilişkisi göz önünde bulundurularak; kariyer yönetimi, yönetici geliştirme, performans yönetimi ve ücretlendirme politikaları hazırlanmalı; prim, terfi gibi firsatların psikolojik sahiplenmeyi etkileyebileceği unutulmamalıdır.

Psikolojik sahiplenmenin çalışan odaklı olması nedeniyle örgütsel adalet, örgütsel bağl1lık, örgütsel destek, hizmetkar liderlik vb. kavramlarla ilişkilerin incelendiği çalışmaların çeşitli sektörler bazında yapılması önerilmektedir. Psikolojik sahiplenmenin olumsuz çıktılarına yönelik karanlık yönünün ele alınabileceği kariyerizm, narsist kişilik, üretkenlik dışı iş davranışları gibi kavramlarla da araştırılması önerilmektedir. İlgili çalışmanın alan yazında yer alan bir boşluğu doldurduğu, araştırmacılar ve uygulayıcılar açısından gelecekte yapılacak olan yeni araştırmalara yol gösterdiği düşünülmektedir.

\section{Kaynakça}

Asatryan, V. S. ve Oh, H. (2008). Psychological ownership theory: an exploratory application in the restaurant industry. Journal of Hospitality \& Tourism Research, 32, 363-386. DOI: $10.1177 / 1096348008317391$.

Avey, J. B., Avolio, B. J., Crossley, C. D., ve Luthans, F. (2009). Psychological ownership: theoretical extensions, measurement and relation to work outcomes. Journal of Organizational Behavior, 30(2), 173-191. doi 10.1002/job.583.

Bekmezci, M ve Yıldız, B. (2019). Yönetim babacan liderlik psikolojik sahipliği nasıl etkilemektedir? kolektif şükranın aracı rolü. İstanbul Ticaret Üniversitesi Sosyal Bilimler Dergisi, 18(35), 309-324.

Belk, R. W. (1988). Possessions and the extended self. Journal Of Consumer Research, 15, 139168. http://dx.doi.org/10.1086/209154.

Brown, G., Lawrence, T. B. ve Robinson, S. L. (2005). Territoriality in organizations. Academy of Management Review, 30(3), 577-594. https://doi.org/10.2307/20159145.

Büyüköztürk, Ş. (2002). Faktör analizi: temel kavramlar ve ölçek geliştirme kullanımı. Kuram ve Uygulamada Eğitim Yönetimi, Güz(32), 470-483.

Dirik, D. ve Eryılmaz, İ. (2016). Psikolojik sahiplenme ve işkoliklik arasındaki ilişkiye yönelik bir araştırma. Süleyman Demirel Üniversitesi İktisadi ve İdari Bilimler Fakültesi Dergisi 21(4), 1433-1448.

Dittmar, H. (1992). Perceived material wealth and first impressions. British Journal of Social Psychology, 31(4), 379-391. https://doi.org/10.1111/j.2044-8309.1992.tb00980.x.

Demirkaya, H. ve Şimşek Kandemir, A. (2014). 21. yüzyılın anahtar rekabet faktörü olan psikolojik sahiplenme üzerine bir işletme incelemesi. ÇSGB Çalışma Dünyası Dergisi, 2(3), 7-21.

Derin, N. (2018). Kuruma duyulan psikolojik sahiplenme ile yenilikçi iş davranışı arasındaki ilişkide sanal kaytarmanın düzenleyici rolü. Hacettepe Üniversitesi İktisadi ve İdari Bilimler Fakültesi Dergisi, 36(1), 63-82. https://doi.org/10.17065/huniibf.411127.

Kalyoncuoğlu, S. (2018). Algılanan kontrolün psikolojik sahiplenmeye etkisinde maksimum fiyatı ödeme istekliliğinin düzenleyici rolü: Mercedes marka otomobil kullanıcıları üzerinde 
bir araştırma. İşletme Araştırmaları Dergisi, 10(3), 974-994. DOI: 10.20491/isarder.2018.509.

Karadal, H., ve Akyazı, T. E. (2015). Psikolojik sahiplenme ile etik olmayan örgüt yanlısı davranışlar arasındaki ilişkinin analizi üzerine Aksaray ilinde bir araştırma. 3. Örgütsel Davranış Kongresi Bildiri Kitabı içinde (ss.111-116), Gaziosmanpaşa Üniversitesi, Tokat.

Karaman, H., Atar, B. ve Çobanoğlu Aktan, D. (2017). Açımlayıcı faktör analizinde kullanılan faktör çıkartma yöntemlerinin karşılaştırılması. GEFAD, 37(3), 1173-1193. DOI: 10.17152/gefad.309356.

Lerner, J. S. ve Tetlock, P. E. (1999). Accounting for the effects of accountability. Psychological Bulletin, 125, 255-275. https://doi.org/10.1037/0033-2909.125.2.255.

Litwinski, L. (1947). The psychology of mine. Philosophy, 22, 240-251. DOI: https://doi.org/10.1017/S003181910000570.

Mayhew, M. G., Ashkanasy, N. M., Bramble, T., ve Gardner, J. (2007). A study of the antecedents and consequences of psychological ownership in organizational settings. The Journal Of Social Psychology, 147(5), 477-500. doi: 10.3200/SOCP.147.5.477-500.

McIntyre, N., Srivastava, A. ve Fuller, J.A. (2009). The relationship of locus of control and motives with psychological ownership in organizations. Journal of Managerial Issues, 21(3), 383-401.

Memmedova, M. ve Ekber, Ş. (2017). Azerbaycan`da bankacılık sektörü çalışanlarının sahiplik duygusu analizine yönelik bir çalışma. MANAS Sosyal Araştırmalar Dergisi, 6(2), 97-114.

Nelson-Jones, R. (1984). Personal Responsibility Counseling and Therapy An Integrative Approach. London: Herper \& Row Publishers.

Ökten, A. B. (2015). Algılanan örgütsel destek ve psikolojik sahiplenme arasındaki ilişki ve bu ilişkide örgütsel adaletin rolü. Hacettepe Üniversitesi Íktisadi ve İdari Bilimler Fakültesi Dergisi, 33(2), 113-140. DOI:10.17065/huiibf.83618.

Pierce, J. L., ve Jussila, I. (2010). Collective psychological ownership within the work and organizational context: construct introduction and elaboration. Journal of Organizational Behavior, 31(6), 810-834. DOI: 10.1002/job.628.

Pierce, J.L., Kostova, T. ve Dirks, K.T. (2001).Toward a theory of psychological ownership in organizations. Academy of Management, 26(2), 298-310. DOI: 10.2307/259124.

Pierce, J.L., S.A. Rubenfeld ve S. Morgan (1991). Employee ownership: a conceptual model of process and effects. Academy of Management Review, 15, 121-144. DOI: 10.2307/258609.

Pierce, J. L. ve Rodgers, L. (2004). The psychology of ownership and worker-owner productivity. Group \& Organization Management, 29(5), 588-613. https://doi.org/10.1177/1059601103254270.

Şimşek Ö. F. (2007). Yapısal eşitlik modellenmesine giriş temel ilkeler ve lisrel uygulamaları. Ankara: Ekinoks Yayınları.

Temizkan, Ö. Y. (2019). Psikolojik güçlendirme ile psikolojik sahiplenme arasındaki ilişkinin değerlendirilmesi: Devlet hastanesi örneği. Ankara Hacı Bayram Veli Üniversitesi İktisadi ve İdari Bilimler Fakültesi Dergisi, 21(3), 640-665.

Uçar, Z. (2016). Kontrol algısı- psikolojik sahiplenme ilişkisi üzerinde algılanan aşırı vasıflılığın düzenleyicilik etkisi. International Journal of Applied Business and Management Studies, 1(1), 40-58.

Uçar, Z. (2018). Psikolojik sahiplik olgusunu örgütsel düzlemde ölçmek için ölçek geliştirme çalışması. İşletme Araştırmaları Dergisi, 10(3), 640-654. DOI: 10.20491/isarder.2018.492. 
Uçar, Z. (2017). Psikolojik sahiplenme: örgütsel alana ilişkin bir model önerisi. Dokuz Eylül Üniversitesi İktisadi ve İdari Bilimler Fakültesi Dergisi, 32(1), 167-200. DOI: https://doi.org/10.24988/deuiibf.2017321552.

Van Dyne, L. ve J.L. Pierce (2004). Psychological ownership and feelings of possession: three field studies predicting employee attitudes and organizational citizenship behavior. Journal of Organizational Behavior, 25, 439-459. https://doi.org/10.1002/job.249.

Yeşil, Ü., Bancar, A. ve Budak, G. (2015). Psikolojik sahiplik kavramına ilişkin bir literatür incelemesi. Eskişehir Osmangazi Üniversitesi Sosyal Bilimler Dergisi, 16(2), 59-82. https://doi.org/10.17494/ogusbd.57630.

\section{ETIKK ve BİLIMSEL İLKELER SORUMLULUK BEYANI}

$\mathrm{Bu}$ çalışmanın tüm hazırlanma süreçlerinde etik kurallara ve bilimsel atıf gösterme ilkelerine riayet edildiğini yazar(lar) beyan eder. Aksi bir durumun tespiti halinde Afyon Kocatepe Üniversitesi Sosyal Bilimler Dergisi'nin hiçbir sorumluluğu olmayıp, tüm sorumluluk makale yazarlarına aittir. 